\title{
How does market react to corporate spin-offs in Australia?
}

\author{
NGUYEN XUAN TRUONG \\ Hanoi University - truongnx@ @anu.edu.vn
}

\section{ARTICLE INFO ABSTRACT}

Article history:

Received:

Sep. 19, 2016

Received in revised form:

Oct. 27, 2016

Accepted:

Dec. 31,2016

Keywords:

Spin-offs

Price reactions

Cumulative abnormal re-

turns.
While numerous studies on spin-off have been done in the US and Europe, little efforts have been directed to research this area of corporate finance in Australia. This study investigates how market reacts to corporate spin-offs in this country. We employ traditional event study methodology and find that market reacts strongly and positively to the announcements of spin-offs. Specifically, the cumulative average abnormal return over the 3 -day event window is $3.58 \%$. The cumulative average abnormal return for spin-offs by companies that increase their industrial focus is $4.12 \%$ and $3.33 \%$ for non-focused increasing spinoffs. Nevertheless, the difference between these two subgroups is statistically insignificant. Multivariate regressions provide evidence that high pre-leverage firms benefit more from spin-offs. 


\section{Introduction}

Corporate divestiture includes asset saleoff, equity carve-out, corporate spin-off, and liquidation ${ }^{1}$. While other types of divestments usually involve cash transaction (i.e. sale-off) or cease of existence of subsidiaries (i.e. liquidation), a spin-off results in creation of a new independent company from a subsidiary or division of the parent company. Shareholders of the parent company will receive shares of the new company on pro rata basis. Upon completion, they hold shares in both the parent firms and the subsidiary. In the US, distributed shares in the subsidiary are considered tax-free dividends $^{2}$. In Australia, spin-off is considered as a "demerger" for tax purpose ${ }^{3}$.

Numerous studies relating to the capital market's reaction to announcements of spinoff has been done using the US and European data. Documented evidence shows that spin-offs create value to its shareholders (see for example Hite \& Owners, 1983; Veld et al., 2008). On average, spin-off announcements are associated with high and significant abnormal stock returns of about $2 \%$ to $3 \%$ or $2.62 \%$ by the US and European firms, respectively. In the long run, shares of engaging firms tend to outperform on a riskadjusted basis (Desai \& Jain, 1999). Although these findings have become "a broad consensus in both the academic and the literatures" (Veld \& Veld-Merkoulova, p.
1112), the rationale claimed for such positive price reaction has been still controversial among researchers. They have provided various reasons to explain the gains, namely "information asymmetry," "wealth transfer," and "getting back to the basics." However, the balance of the empirical literature seems to favor the "getting back to the basics" hypothesis. It states that restructuring through spin-off might reduce diversification discount from previous merger and acquisition and even turn the discount into premium (Allen et al., 1995).

While numerous studies on spin-off have been done in the US and Europe, efforts have not been directed to research this area of corporate finance in Australia. Probably, it is because there were few corporate spinoffs in Australia prior to $2002^{4}$. Since then spin-offs have become more popular in Australia; for instance, 14 spin-offs took place in 2004. This provides us an opportunity to undertake a study of spin-offs in Australia. Particularly, this study has two fold purposes: (i) to examine whether spin-off announcements of Australian firms experience significantly positive market reactions; and (ii) to explain the potential gains or loss to shareholders following the spin-off events.

This paper will be organized as follows. Section 2 begins with the examination of the prior literature to develop testable hypotheses. Section 3 outlines the data processing

\footnotetext{
${ }^{1}$ See Ross (2011). Sell-off occurs when a company sells either a division or a subsidiary. Equity carve-out occurs when a company sells its stocks in a subsidiary to the public but still retains controlling interest. It is also considered as partial spinoff. Liquidation occurs when an insolvent company sells its assets either voluntarily or in bankruptcy.
}

\footnotetext{
${ }^{2}$ See Krishnaswami and Subramaniam (1999)

${ }^{3}$ See: Section 125-70 of the ITAA 97 - Demerger roll-over relief, Income Tax Assessment Act 1997

${ }^{4}$ Cooney et al. (2008) document five spin-offs in Australia prior to 2002
} 
and research methodology. Section 4 presents the empirical results and discussion of the findings. Finally, Section 5 provides a conclusion and some suggestions for future research in the spin-off arena in Australia.

\section{Literature review}

2.1. Overview of spin-off announcement returns

Spin-offs usually receive positive market reactions because it is one of value creation techniques in corporate actions (Berger \& Ofek, 1995; Thomas \& Yan, 2004; Veld \& Veld-Merkoulova, 2008). During the 1980s, number of divestiture in general and spinoffs in particular in the US increase so substantially that Schmidt (1987, p.26) predicted that "divestiture may be to the 1980s what conglomeration was to the 1960s." Spin-off as one type of divestiture also receives much attention from researchers and there have been plenty of published papers on this area during the 1980s and 1990s. In general, findings from those papers demonstrate that spin-off announcements are associated with positive abnormal stock returns.

Hite and Owners (1983) examined 123 voluntary spin-offs in the US from 1963 to 1981 and documented a general abnormal

\section{Table 1}

A comparison of cumulative abnormal returns (CAR) observed in previous studies

Authors

Market Methodology Event dates Size

CAR $(\%)$

Hite and Owners

(1983)

Schipper and Smith

(1983)

Allen et al.

(1995)

Krishnaswami and Subrama-

niam

(1999)

Veld-Merkoulova

(2004)

Veld-Merkoulova

(2008)

Zakaria and Arnold

(2012)
US MAR

US

MM

MM

US

US

Europe

MM

US

MM

Malaysia

MM

$$
(-1,0)
$$

(1963-1981)

(1963-1981)

(1962-1991)

(1979-1993)

$(-1,1)$

(1987-2000)

$(-1,1)$

(1995-2002)
118

$3.15^{* * *}$

$3.28 * * *$

$3.30^{* * *}$

$2.84 * * *$

$2.15 * * *$

156

$2.62 * * *$

91

$3.07 * * *$

$5.04 * *$ 
return of $3.3 \%$ in the two day window. They find a positive relationship between the size of spin-offs and the value gains to the parent companies. Another paper by Schipper and Smith (1983), who investigated 93 spin-offs during the same period, also concludes that stockholders receive an abnormal average return of $2.84 \%$. Allen et al. (1995) extended the study period from 1962 to 1991, reporting that market reacts positively to spin-off announcements with an average abnormal stock return of $2.15 \%$ in the two day event. Krishnaswami and Subramaniam (1999) documented significant abnormal returns of more than 3\% in their research, using the US data. Another interesting finding is that spinoffs also provided positive abnormal returns in the long run, i.e. 3 year period (Cusatis et al., 1993). More recently, Veld and VeldMerkoulova (2008) also confirm that spinoff announcements by the US firms create value to the shareholders i.e., abnormal stock return of $3.07 \%$ during a three day window.

Since spin-offs do create value to stockholders in the US markets, researchers are keen on extending research into other markets such as European and emerging markets (Malaysia and Singapore). Veld and VeldMerkoulova (2004) investigated 156 spinoffs across 15 different European countries, finding that spin-offs create a gain of $2.62 \%$ over three day window; but they find no evidence to support a long-term gain from spin-offs as documented in the US. Yoon and Ariff (2007) conducted a study with 85 sample firms in Malaysia over 23 year period from 1980 to 2008, reporting a surprisingly high level of abnormal stock returns of the parent firms, which is $22.7 \%$ for a two day window. This is around 5 to 6 times higher than that of US and European markets. This surprise comes to the attention of other researchers, namely Zakaria and Arnold (2012). They performed a study of spin-offs in Malaysia for a longer period, i.e. 28 years from 1980 to 2008 with a sample o f only 36 transactions. They find that average abnormal stock return following the spin-off announcements in Malaysia is only $5.06 \%$. Thus, they suspect that the study made by Yoon and Ariff is "not purely focused on spin-offs."

\subsection{Sources of gains from spin-offs}

Going beyond the documented excess returns through spin-offs, researchers try to explain the sources of these value gains. A broad consensus is that a spin-off helps unlock hidden value of a firm's division that is difficult to evaluate separately. Other reasons for spin-offs vary widely such as undervaluation of stock, getting back to the basics, merger and acquisition facilitation, and financial flexibility. In fact, numerous hypotheses have been proposed to explain these sources: the focus hypothesis, the wealth transfer hypothesis, and the information asymmetry hypothesis, among others.

Getting back to the basics ${ }^{5}$ : The very well-known benefits of diversification are
${ }^{5}$ This term was used by Hite and Owner (1983) to categorize
firms spinning off their non-core business divisions. This
group of firms has the largest abnormal return of $14.5 \%$ other/no reasons. 
synergies created. In some cases, however, firms experience negative synergies and diversification discount would then exist. Diversification discounts result from inefficiency in allocation of resources among the divisions of diversified firms. Campa et al. (2002, p.1760) argued that "firms that refocus their operations would have suffered a significant decrease in value if they had remained diversified." The hypothesis receives the most supporting evidence from empirical research. It seems to be a consensus among researchers when explaining the value gains through spin-offs. Hite and Owners (1983) verify a significantly positive abnormal return of $14.5 \%$ for the group of spin-off with refocusing-related motive. Daley et al. (1997) find an average positive abnormal return of $4.5 \%$ for the group of cross-industry spin-offs. Their evidence ${ }^{6}$ is consistent with the hypothesis that spin-offs create value when firms remove their unrelated businesses because this helps management focus on what they can do best.

Wealth transfer hypothesis: Galai and Masulis (1976, p.69) stated that there will be a redistribution of wealth between stockholders and bond holders as "the stockholders have 'stolen away' a portion of the bond holders' collateral since they no longer have any claim on the assets of the new firm." Thus, one possible source of gain from spinoffs to equity holders would come at the expense of debt holders. Findings from different research studies provide conflicting results as the parent firms might transfer the claims to the spun-offs; therefore, cash flows generated from the spun-off assets still have to support the claims. While Hite and Owner (1983) find no evidence to support the wealth transfer hypothesis; Schipper and Smith (1983) find very little evidence of a wealth transfer from bond holders to stockholders. On the other hand, findings of Maxwell and Rao (2003), and Veld and VeldMerkoulova (2008) support this hypothesis.

Information asymmetry hypothesis: Habib et al. (1997) presented an information-based explanation for spin-offs. They argued that spin-off is a way to make information more available to the market: information is transmitted from managers to uninformed investors. Krishnaswami and Subramaniam (1999) also documented that firms engaging in spin-offs usually have higher level of information asymmetry than other peers in the same industries. By using the analyst's earnings forecast errors and other measures of information asymmetry, they conclude that there is a substantial reduction of information asymmetry after completion of spin-offs. Their findings are in line with the information hypothesis. The information hypothesis maintains that managers often have better and more concrete information about the company's operations than outsiders. It is therefore more difficult for outsiders to evaluate and appraise the performance of a firm. The information regarding individual divisions or subsidiaries is not often provided to investors separately; it is consolidated on the financial statements

\footnotetext{
${ }^{6}$ Their paper addressed the question whether value creation through spinoff comes from the improvement in operating performance or/and from bonding benefits.
} 
with few footnotes. The situation is getting more difficult for investors when firms become more complex in their structure and more diversified in their businesses. When spin-off is to create a publicly traded entity, more information will be available to investors. As a result, the spun-off assets will be appraised better (Krishnaswami \& Subramaniam, 1999). Later studies on spin-offs, such as Bergh et al. (2008), conclude that restructuring through spin-offs can mitigate information asymmetry and enhance value by providing more information of the spun-off assets to capital markets. They also discuss the information content hypothesis in the case of asset sell-offs.

Relative size of spin-offs: Existing literature shows that the bigger the portion of divested asset, the higher the price appreciation to the shares of the parent firms. Miles and Rosenfeld (1983), who examined 92 spin-offs by the US from 1963 to 1980 s, find a CAAR (cumulative adjusted abnormal return) of $24.53 \%$ for the large spin-offs and only $12.62 \%$ for the small spin-offs ${ }^{7}$. Other studies by Krishnaswami and Subramaniam (1999) and Veld and Veld-Merkoulova (2008) also support this hypothesis.

\section{Research design}

This study investigates how market reacts to the announcements of spin-offs as well as to the record dates of the events using Australian data. We also discuss the motivations for Australian firms to spin off their subsidiaries during 2002 to 2011. Event study methodology and multivariate analysis will be employed to facilitate discussion of corporate spin-offs in Australia.

\subsection{Data}

Announcement dates of spin-offs from the period 2002 and 2011 were obtained from Bloomberg Database. The restricted criteria were set to collect data that best suits the objectives of this study and to facilitate the requirement of event study methodology. Only completed deals done by Australian publicly traded firms on ASX were selected. Terms of the spin-off must be specified. This process resulted in a selection of 61 spin-off announcements, along with information pertaining to the ASX codes of parent and spun-off firms and announcement dates, record dates, and payment dates. To verify spin-off announcements, MorningstarTM DatAnlysis was used to obtain the announcement documents. This process eliminated 42 spin-off announcements which happened at the same time with other significant corporate events such as right issues, share buy-back, reverse split. This process is to facilitate the requirements of the event study. Because spin-offs can be easily confused with several types of return of capital (i.e. disposal of asset in exchange of shares of another public listed firms, equal distribution of share investment in other firms, and equity carve-out), a thorough scan at announcement-related documents were performed to exclude those types of share

Small spinoff: Ratio of market value of the spun-off division or subsidiary to market value of the firm's common stock is less than $10 \%$ ${ }^{7}$ Large spinoff: Ratio of market value of the spun-off division
or subsidiary to market value of the firm's common stock is
greater or equal $10 \%$. 
distribution. Accordingly, 40 returns of capital were then excluded, which leads to the final sample of 61 announcements. Table 2 below summaries those steps in chronological order.

\section{Table 2}

Summary of sample selection

\begin{tabular}{lc}
\hline Reason of exclusion & $\begin{array}{c}\text { Obser- } \\
\text { vations }\end{array}$ \\
\hline Initial sample of AUS & 188 \\
Exclusion: & 10 \\
Insufficient data and information & 42 \\
Contaminated information & 10 \\
$\begin{array}{l}\text { Spin-off of trust, funds or jointly } \\
\text { sponsored spin-offs }\end{array}$ & 05 \\
Equity carve-out & 20 \\
Asset sale in exchange of share & 40 \\
Other return of share capital & 127 \\
$\quad$ Total exclusions & 61 \\
\hline
\end{tabular}

\subsection{Cumulative average abnormal re-} turn

This paper employs event study methodology used with daily stock returns proposed by Brown and Warner (1985) to examine the share price impacts of firm-specific events (e.g. spin-off announcements). First, the event windows are grouped into three categories namely pre-announcement period, announcement period, and post-announcement period, of which the announcement date is defined as day 0 and other periods are set relatively to this date (Table 3 ). Second, it is required to compute the abnormal return (or excess return), which, as defined by MacKinlay (1997), is "the actual ex-post return of the security over the event window minus the normal return of the firm over the event window."

Table 3

Even windows and price reactions

Effects Event window (days)

\begin{tabular}{ll}
\hline Exami- & 261 days before announcement \\
nation & date to 61 days before announce- \\
period & ment date (day -261 to day -61)
\end{tabular}

Pre-an- 61 days before the announcement nounce- date (day -61)

ment

An- Announcement day (day 0)

nounce- Announcement day to first day ment after the announcement date (day 0 to day +1 ),

1 day before announcement date and 1 day after announcement date (day -1 to day +1$)$

Post-an- 2 days after announcement date nounce- to 60 days after announcement ment date $($ day +2 to day +60$)$

The following formula is used to estimate abnormal returns:

$$
A b_{j t}=R_{j t}-E\left(R_{j t}\right)
$$

where:

$$
\begin{aligned}
& A b_{j t}=\text { abnormal return of event } j \text { on day } t \\
& R_{j t}=\text { ex-post return of event } j \text { on day } t \\
& E\left(R_{j t}\right)=\text { ex-ante return of event } j \text { on day } t
\end{aligned}
$$


Let $R_{j t}$ be the actual return on share $j$ at day t. Designate $\mathrm{P}_{\mathrm{jt}}$ and $\mathrm{P}_{\mathrm{jt}-1}$ prices of share on day $\mathrm{t}$ and $\mathrm{t}-1$ respectively; $\mathrm{D}_{\mathrm{jt}}$ the dividend, if any, paid on day t. For every share, the actual return for each day is calculated in continuous form as follows:

$$
R_{j t}=\ln \left[\frac{\left(P_{j t}+D_{j t}\right)}{P_{j t-1}}\right]
$$

Researchers opt to select mean adjusted return and/or market model to find the expected returns for securities. However, Market Model is chosen for this study to identify expected returns for several reasons. First, period of study is 10 years long from 2002 to 2011 during which market has experienced dynamic changes. Second, Brown and Warner (1985) argued that the use of market model is itself sufficient and well specified under variety of conditions. Third, this method has been widely employed in the studies of corporate divestiture and spin-off events (see for example Brown \& Warner, 1983; Krishnaswami \& Subramaniam, 1999).

For each share, we calculate expected return for event day $\mathrm{t}$ as follows:

$$
R_{j t}=\alpha_{i}+\beta_{j t} R_{m t}+\varepsilon_{j t}
$$

where:

$\mathrm{R}_{\mathrm{jt}}=$ observed return for security $\mathrm{j}$ on day $\mathrm{t}$

$\alpha_{\mathrm{jt}}=$ constant term

$\beta_{\mathrm{jt}}=$ beta coefficient of security $\mathrm{j}$ on day $\mathrm{t}$

$\mathrm{R}_{\mathrm{mt}}=$ observed return on the market on day $\mathrm{t}$

$\varepsilon_{\mathrm{it}}=$ error term

By rearranging Equation (3), abnormal returns can be estimated:

$$
\varepsilon_{j t}=R_{j t}-\left(\alpha_{i}+\beta_{j t} R_{m t}\right)
$$

The consensus proxy for the market return used in Australia is the Australian All Ordinaries Index. Estimator $\alpha_{\mathrm{j}}$ and $\beta_{\mathrm{j}}$ (i.e. model parameters) are calculated using an estimation period commencing 261 days before announcement date to 61 days before announcement date.

Daily abnormal returns $\left(\mathrm{AR}_{\mathrm{t}}\right)$ for each security with respect to specific time interval are summed over to obtain the following:

$$
A R_{j t}=\sum_{t=-1}^{1} \varepsilon_{j t}
$$

Then, we derive average cumulative abnormal return (CAR) by taking arithmetic mean of the summation from Equation (5) across all observations in the sample. The CAR represents the aggregate price reactions of the firms in the sample over the selected event window. For example, CAR for the event window day -1 to day +1 is calculated ( $\mathrm{AR}_{\mathrm{t}}$ denotes summation of daily $\mathrm{ab}$ normal return for each security during 3 days).

$$
C A R_{j t}=\frac{1}{N} \sum_{j=1}^{1} A R_{j t}
$$

In accordance with the use of market model to calculate the abnormal returns, we employ standardized residual test for the significance of the result (see for example $\mathrm{Pa}$ tell, 1976; Brown \& Warner, 1985). The advantage of this method is that it helps reduce type I error of rejecting a null hypothesis (e.g., mean abnormal returns are zero). The error could happen if there are substantial increases in the variance of share returns around announcement dates. To induce type 
I error and allow for out of sample estimation error, it is necessary to standardize the abnormal returns. In this instance, abnormal returns will be divided by the standard error of the market model. The formula is as follows:

$$
S R_{j t}=\frac{A R_{j t}}{S\left(\varepsilon_{j t}\right)}
$$

where:

$A R_{j t}=$ summation of daily abnormal return of security $\mathrm{j}$ during a period

$S\left(\varepsilon_{j t}\right)=$ standard error of abnormal returns estimated from market model

Subsequently, the test statistic is as follows

$$
T_{\text {stat }}=\sum_{j=1}^{N_{t}} S R_{j t} \times\left(N_{t}\right)^{-1}
$$

where $\mathrm{N}_{\mathrm{t}}$ denotes the number of sample securities at day $t$ and $T_{\text {stat }}$ is distributed unit normal for large number of sample securities.

\subsection{Multivariate analysis}

The dependent variable is the CAR for the event period from day -1 to day +1 . The constant term " $\mathrm{C}$ " is included in all models as an intercept to validate the third assumption underlying the ordinary least squared method (OLS) (i.e. the mean value of the residual term is zero (Gujarati, 2004, p.64). To ensure constant variance of the error terms (i.e. forth assumption - homoscedasticity), all regression models estimated will be White Heteroskedasticity-Consistent Standard Errors \& Covariance. All of the five models do not suffer serious multicollinearity (i.e. third assumption — non multicollinearity) since pair-wise correlation coefficient between each and every two independent variables are smaller than 0.8 (basic econometrics, p.359). The final assumption of the OLS (optional assumption) requires that the disturbance term to be normally distributed. Consequently, normality Jarque-Bera tests are performed. Ramsey RESET tests are done to ensure that models are well-specified. Table 4 presents the general definition of independent variables.

\section{Table 4}

Definition of the variables used in the

\begin{tabular}{|c|c|}
\hline Variable & Description \\
\hline AMMN1P1 & $\begin{array}{l}=\text { dependent variable, being cu- } \\
\text { mulative abnormal returns esti- } \\
\text { mated from the Market Model } \\
\text { for the event window (day }-1 \text { to } \\
\text { day }+1) \text {. Number of observa- } \\
\text { tion }(\mathrm{N})=61\end{array}$ \\
\hline LISTED & $\begin{array}{l}=\text { dummy independent varia- } \\
\text { ble, taking value of } 1 \text { if spun- } \\
\text { off firm is a listed public com- } \\
\text { pany, otherwise is zero. }\end{array}$ \\
\hline FOCUS & $\begin{array}{l}=\text { dummy independent varia- } \\
\text { ble, taking value of } 1 \text { if the par- } \\
\text { ent firm and spun-off firm have } \\
\text { different GISC sectors, other- } \\
\text { wise is zero. This might indi- } \\
\text { cate that the parent firm operate } \\
\text { in multi-segments (Campa et } \\
\text { al., 2002) }\end{array}$ \\
\hline LF & $\begin{array}{l}=\text { multiplicative form of } \\
\text { LISTED and FOCUS, being } 1 \\
\text { if the parent firm spinning off }\end{array}$ \\
\hline
\end{tabular}
study 


\begin{tabular}{ll}
\hline Variable & Description \\
\hline & its subsidiary into different in- \\
& dustry and the spun-off firm is \\
& listed on ASX. \\
& $=$ independent variable, being \\
& the relative size of the spin-off \\
firms to the sum of market & value of the parent firm and the \\
Spun-off upon the completion \\
of spin-offs (Krishnaswami et \\
al., 1999). \\
= independent variable, being \\
the relative firm size of the par- \\
ent firm 30 days prior to the \\
spin-off announcement. It is in \\
natural logarithm form. \\
= independent variable, being \\
the pre-leverage ratio of the \\
parent firm. It is a ratio of total \\
debt to total assets on the latest \\
balance sheet prior to spin-off. \\
= independent variable, being \\
cash ratio of the parent firm. It \\
is a ratio of total cash to total \\
assets on the latest balance \\
sheet prior to spin-off. \\
260 to day -2. \\
\end{tabular}

\section{Findings and discussion}

\subsection{Price reaction to the spin-off an- nouncements}

The event study results for the sample of 61 spin-offs in Australia are presented in Table 5. In general, all event windows (for example: 2 day around announcement dates -
$A D-1$ to $A D+1)$ report positive abnormal stock returns. The results show a cumulative average abnormal return of $3.58 \%$ for the event window from day -1 to day +1 . This abnormal return is significant at $1 \%$ level. It is plausible that the abnormal returns for other bigger and smaller events windows e.g. day -2 day to day +2 and day -1 to day 0 are also significant at $1 \%$ level. Respectively, the cumulative abnormal average returns for the 5 days event (day -2 to day +2 ) and 2 day event (day -1 to day 0 , and day 0 to day +1 ) are $3.96 \%, 2.97 \%$, and $3.13 \%$. Accordingly, there is evidence to support the hypothesis that market reacts positively to the announcement of spin-off. Thus, this infers that spin-off creates value to shareholders. This finding is consistent with existing literature for the US and European firms, which reports positive stock abnormal returns of between $2.15 \%$ to $3.3 \%$ (Krishnaswami \& Subramaniam, 1999; Veld \& Veld-Merkoulova, 2004).

\subsection{Price reaction to the record dates} of spin-offs

Australian firms engaging in spin-off, in general, experience negative abnormal returns of its stock during the period of record dates. The result shows a cumulative average abnormal rerun of $-3.03 \%$ for the three day around record dates. This is significant at $1 \%$ level. The other smaller event windows (pre- and post-record dates) also reveal negative stock price reaction. However, the cumulative average abnormal return for day -1 to 0 is statistically insignificant at $10 \%$ level while significant at $1 \%$ level for the other window, i.e., day 0 to +1 . These results 


\section{Table 5}

Price reaction to the spin-off announcement and record dates

\begin{tabular}{|c|c|c|c|}
\hline Event window & & & Whole sample \\
\hline \multirow{20}{*}{ Announcement period } & $\mathrm{AD}-2$ to $\mathrm{AD}+2$ & Mean & 3.96 \\
\hline & & Median & 1.65 \\
\hline & & Size & 61 \\
\hline & & SRT & $7.03 * * *$ \\
\hline & $\mathrm{AD}-1$ to $\mathrm{AD}+2$ & Mean & 3.83 \\
\hline & & Median & 1.20 \\
\hline & & Size & 61 \\
\hline & & SRT & $6.59 * * *$ \\
\hline & $\mathrm{AD}-1$ to $\mathrm{AD}+1$ & Mean & 3.58 \\
\hline & & Median & 2.13 \\
\hline & & Size & 61 \\
\hline & & SRT & $(6.41)^{* * *}$ \\
\hline & $\mathrm{AD}-1$ to $\mathrm{AD} 0$ & Mean & 2.97 \\
\hline & & Median & 1.24 \\
\hline & & Size & 61 \\
\hline & & SRT & $(4.39) * * *$ \\
\hline & $\mathrm{AD} 0$ to $\mathrm{AD}+1$ & Mean & 3.13 \\
\hline & & Median & 0.65 \\
\hline & & Size & 61 \\
\hline & & SRT & $(5.89)^{* * *}$ \\
\hline \multirow{8}{*}{ Record period } & $\mathrm{RD}-1$ to $\mathrm{RD}+1$ & Mean & -3.03 \\
\hline & & Median & -0.42 \\
\hline & & Size & 61 \\
\hline & & SRT & $(-2.90)^{* * *}$ \\
\hline & $\mathrm{RD}-1$ to $\mathrm{RD} 0$ & Mean & -2.22 \\
\hline & & Median & -0.46 \\
\hline & & Size & 61 \\
\hline & & SRT & $(-1.41)$ \\
\hline
\end{tabular}




\begin{tabular}{lll}
\hline RD 0 to RD +1 & Mean & -2.20 \\
& Median & -0.73 \\
& Size & 61 \\
& SRT & $(12.18)^{* * *}$ \\
\hline
\end{tabular}

\begin{abstract}
Notes: This table reports mean and median abnormal returns and the standardized residual t-tests (SRT) for the period the day before the announcement date to day after (e.g. AD-1 TO AD 1), day before the record date to day after (e.g. RD -1 TO RD 1). This table reports listed versus unlisted spun-off firms. This table also provides t-test statistics for the difference in mean abnormal returns across the different groupings.
\end{abstract}

*Significantly different from zero at the $10 \%$ level,

**Significantly different from zero at the $5 \%$ level, and

***Significantly different from zero at the $1 \%$ level.

support the hypothesis that market react negatively to the announcement of stock distribution of the spin-offs.

On the record date, stock capital of the parent firms will be reduced by an amount equal to the value of the spun-off assets. The companies also determine eligible shareholders for receiving the free spun-off stocks on that date. Therefore, it is expected that stock price of the parent companies will drop after the record dates. Hite and Owners (1983) report a drop-off of the cumulative excess return after the announcement dates for the sample of the US firms. Veld and Veld-Merkoulova (2008) find a drop-off of the cumulative excess return for a longer period of 3 years after the spin-off announcements for the European firms. The existing literature does not examine the impact of the announcement of share distribution during the record dates. This study, therefore, attempts to contribute to the existing literature of corporate spin-offs by providing some insights into how market reacts to the share distribution around the record dates.

\subsection{What motivates Australian firms to} spin off its divisions?

Results from existing literature provide evidence to support several motives why American and European firms do spin-off, for example, to get back to the basics, to improve information transparency (see for example Hite \& Owners, 1983; Krishnaswami \& Subramaniam, 1999). In this paper, we are about to test their hypotheses using Australian data.

Do Australian firms spin off its divisions for the purpose of increased focused strategy? Existing literature suggests two possible approaches to test the "getting back to the basics" hypothesis. The first approach is to examine merger and acquisition related spin-offs in which the target was the parent firm (Hite \& Owners, 1983; Allen et al., 1995). The second approach is to examine cross-industry and same industry spin-offs. Accordingly, increased industrial focus 
spin-offs are those whose spun-off firms operate in different industry of the parent firms. Non-focus increasing spin-offs are those whose spun-off subsidiaries operate in the same industry of the parent firms. Numerous studies strongly support the hypothesis that cross-industry spin-offs are associated with higher abnormal stock returns than same-industry spin-offs (e.g., Daley et al., 1997; Krishnaswami \& Subramaniam, 1999). Specifically, Maxwell and Rao (2003) find that cross-industry spin-offs had an average abnormal return of $4.2 \%$ whereas that of same-industry spin-offs is only $0.96 \%$. This study follows the second approach. We expect that market reacts more strongly and positively to the cross-industry spin-offs than the same industry spin-offs.

Table 6 demonstrates that positive abnormal return of $4.21 \%$, significant at $1 \%$ level, for the group of focused spin-offs (17 announcements). It also shows a positive abnormal return of $3.33 \%$, significant at $1 \%$ level, for the group of non-focused spin-offs (44 announcements). However, the t statistic value of -0.36 implies that there is no significant difference between mean abnormal cumulative returns between the two groups. The other event windows (e.g. AD -1 to AD +2 , AD- 1 to $\mathrm{AD}+1, \mathrm{AD}-1$ to $\mathrm{AD} 0, \mathrm{AD} 0$ to $\mathrm{AD}+1$ ) also reveals the same patterns. These results are not in line with the findings on the US market. For example, Daley et al. (1997) find that cross industry spin-offs experiences an average abnormal return of $4.5 \%$, statistically different from a group of the same industry spin-offs.

Do spin-offs in Australia enhance information symmetry? This study employs a broader definition of spin-off, which states that "spin-off is a type of divestiture, in which shares of spun-off firms will be distributed to existing shareholders of parent firms." Australian firms choose to divest their assets through spin-off either in the form of establishing public listed firms or unlisted firms. Both types result in forming an independent and separate form of business from the parent firm. However, only pubic listed firms are subject to the strict regulation of stock exchange on regular release of performance-related information to the market. Such spin-offs help reduce information asymmetry, while spin-offs into unlisted firms do not. In addition, it is more costly and difficult to trade unlisted stocks (Edelman \& Baker, 1990). Thus, we expect that market reacts negatively to the spin-off into unlisted company.

The cumulative average abnormal returns generated from market model for the sub-group of unlisted spin-off are both positive and statistically significant at $1 \%$ and $5 \%$ level for the period from day -2 to day +2 , day -1 to day +2 , and day -1 to day +1 , respectively. The evidence is against the hypothesis that market reacts negatively with the spin-off in which spun-off firms are unlisted public company. It is interesting that there is no significant difference between two subsample of listed and unlisted spinoff. Thus, there is evidence to support that market, in general react positively with spinoff announcements regardless of the business form of spun-off assets. 


\section{Table 6}

Price reaction to the spin-off announcement (focus vs. non-focus spun-off assets)

\begin{tabular}{|c|c|c|c|c|c|c|}
\hline Event window & & $\begin{array}{l}\text { Sta- } \\
\text { tistics }\end{array}$ & $\begin{array}{l}\text { Whole } \\
\text { sample }\end{array}$ & Focused & $\begin{array}{l}\text { Non-Fo- } \\
\text { cused }\end{array}$ & t-test \\
\hline \multirow{25}{*}{ Announcement } & \multirow[t]{5}{*}{$\mathrm{AD}-2$ to $\mathrm{AD}+2$} & Mean & 3.96 & 5.62 & 3.32 & \multirow[t]{5}{*}{-0.62} \\
\hline & & Me- & 1.65 & 2.35 & 1.52 & \\
\hline & & dian & 61 & 17 & 44 & \\
\hline & & Size & $7.03 * * *$ & $4.09 * * *$ & $5.74 * * *$ & \\
\hline & & SRT & & & & \\
\hline & \multirow[t]{5}{*}{$\mathrm{AD}-1$ to $\mathrm{AD}+2$} & Mean & 3.83 & 5.68 & 3.12 & \multirow[t]{5}{*}{-0.77} \\
\hline & & Me- & 1.20 & 2.44 & 1.18 & \\
\hline & & dian & 61 & 17 & 44 & \\
\hline & & Size & $6.59 * * *$ & $3.92 * * *$ & $5.33 * * *$ & \\
\hline & & SRT & & & & \\
\hline & \multirow[t]{5}{*}{$\mathrm{AD}-1$ to $\mathrm{AD}+1$} & Mean & 3.58 & 4.21 & 3.33 & \multirow[t]{5}{*}{-0.36} \\
\hline & & Me- & 2.13 & 2.24 & 2.05 & \\
\hline & & dian & 61 & 17 & 44 & \\
\hline & & Size & $(6.41)^{* * *}$ & $(4.01)^{* * *}$ & $(5.05)^{* * *}$ & \\
\hline & & SRT & & & & \\
\hline & \multirow[t]{5}{*}{$\mathrm{AD}-1$ to $\mathrm{AD} 0$} & Mean & 2.97 & 4.64 & 2.33 & \multirow[t]{5}{*}{-1.02} \\
\hline & & Me- & 1.24 & 1.68 & 0.69 & \\
\hline & & dian & 61 & 17 & 44 & \\
\hline & & Size & $(4.39) * * *$ & $(3.33)^{* * *}$ & $(3.10)^{* *}$ & \\
\hline & & SRT & & & & \\
\hline & \multirow[t]{5}{*}{$\mathrm{AD} 0$ to $\mathrm{AD}+1$} & Mean & 3.13 & 2.72 & 3.28 & \multirow[t]{5}{*}{0.29} \\
\hline & & Me- & 0.65 & -0.29 & 1.37 & \\
\hline & & dian & 61 & 17 & 44 & \\
\hline & & Size & $(5.89)^{* * *}$ & $(2.77)^{* *}$ & $(5.22)^{* * *}$ & \\
\hline & & SRT & & & & \\
\hline \multirow{5}{*}{ Record } & \multirow[t]{5}{*}{ RD - 1 to RD +1 } & Mean & -3.03 & 1.48 & -4.77 & \multirow{5}{*}{$\begin{array}{l}- \\
2.11 * *\end{array}$} \\
\hline & & $\mathrm{Me}-$ & -0.42 & 1.41 & -0.72 & \\
\hline & & dian & 61 & 17 & 44 & \\
\hline & & Size & $(-2.90) * * *$ & $(2.64)^{* *}$ & $(-$ & \\
\hline & & SRT & & & $5.06) * * *$ & \\
\hline
\end{tabular}




\begin{tabular}{lllllll}
\hline RD -1 to RD 0 & Mean & -2.22 & 0.28 & -3.19 & -1.41 \\
& Me- & -0.46 & -0.27 & -0.54 & \\
& dian & 61 & 17 & 44 & \\
& Size & $(-1.41)$ & $(1.11)$ & $(-2.35)^{* *}$ & \\
& SRT & & & & \\
\cline { 2 - 6 } RD 0 to RD +1 & Mean & -2.20 & 0.08 & -3.08 & -1.41 \\
& Me- & -0.73 & 0.23 & -1.08 & \\
& dian & 61 & 17 & 44 & \\
& Size & $(12.18)^{* * * *}$ & $(1.38)$ & $(-$ & \\
& SRT & & & $3.78)^{* * *}$ & \\
\hline
\end{tabular}

Notes: This table reports mean and median abnormal returns and the standardized residual t-tests (SRT) employing the market model for spin-off announcements for the period the day before the announcement date to day after (e.g. AD-1 TO AD 1), day before the record date to day after (e.g. RD -1 TO RD 1), and "bigger" window - the day before announcement dates and the days after the record dates (e.g. AD-1 to RD +1). This table reports focused versus non-focused spin-off. This table also provides t-test statistics for the difference in mean abnormal returns across the different groupings.

*Significantly different from zero at the $10 \%$ level,

**Significantly different from zero at the $5 \%$ level, and

***Significantly different from zero at the $1 \%$ level. 


\section{Table 7}

Price reaction to the spin-off announcement (listed vs. unlisted spun-off assets)

\begin{tabular}{|c|c|c|c|c|c|c|}
\hline Event window & & & Whole sample & Listed firms & Unlisted & t-test \\
\hline \multirow{20}{*}{$\begin{array}{l}\text { Announcement } \\
\text { period }\end{array}$} & $\mathrm{AD}-2$ to $\mathrm{AD}$ & Mean & 3.96 & 2.98 & 7.96 & 1.21 \\
\hline & +2 & Median & 1.65 & 1.30 & 6.51 & \\
\hline & & Size & 61 & 49 & 12 & \\
\hline & & SRT & $7.03 * * *$ & $6.09 * * *$ & $3.55^{* * *}$ & \\
\hline & $\mathrm{AD}-1$ to $\mathrm{AD}$ & Mean & 3.83 & 3.29 & 6.05 & 0.70 \\
\hline & +2 & Median & 1.20 & 1.13 & 2.13 & \\
\hline & & Size & 61 & 49 & 12 & \\
\hline & & SRT & $6.59 * * *$ & $5.76 * * *$ & $3.23 * *$ & \\
\hline & $\mathrm{AD}-1$ to $\mathrm{AD}+1$ & Mean & 3.58 & 3.12 & 5.44 & 0.85 \\
\hline & & Median & 2.13 & 1.17 & 3.10 & \\
\hline & & Size & 61 & 49 & 12 & \\
\hline & & SRT & $(6.41)^{* * *}$ & $(5.95)^{* * *}$ & $(2.43)^{* *}$ & \\
\hline & $\mathrm{AD}-1$ to $\mathrm{AD} 0$ & Mean & 2.97 & 2.50 & 4.88 & 0.93 \\
\hline & & Median & 1.24 & 0.61 & 4.28 & \\
\hline & & Size & 61 & 49 & 12 & \\
\hline & & SRT & $(4.39) * * *$ & $(3.93)^{* * *}$ & $1.95^{*}$ & \\
\hline & $\mathrm{AD} 0$ to $\mathrm{AD}+1$ & Mean & 3.13 & 2.95 & 3.83 & 0.39 \\
\hline & & Median & 0.65 & 0.52 & 2.34 & \\
\hline & & Size & 61 & 49 & 12 & \\
\hline & & SRT & $(5.89)^{* * *}$ & $(5.85)^{* * *}$ & 1.47 & \\
\hline \multirow{8}{*}{$\begin{array}{l}\text { Record } \\
\text { period }\end{array}$} & $\mathrm{RD}-1$ to $\mathrm{RD}+1$ & Mean & -3.03 & -2.18 & -6.51 & -1.27 \\
\hline & & Median & -0.42 & -0.42 & -1.08 & \\
\hline & & Size & 61 & 49 & 12 & \\
\hline & & SRT & $(-2.90) * * *$ & $(-2.40)^{* *}$ & $(-1.70)$ & \\
\hline & $\mathrm{RD}-1$ to $\mathrm{RD} 0$ & Mean & -2.22 & -1.33 & -5.87 & -1.64 \\
\hline & & Median & -0.46 & -0.40 & -1.17 & \\
\hline & & Size & 61 & 49 & 12 & \\
\hline & & SRT & $(-1.41)$ & $(-0.69)$ & $(1.80)^{*}$ & \\
\hline
\end{tabular}




$\begin{array}{llllll}\text { RD 0 to RD +1 } & \text { Mean } & -2.20 & -1.85 & -3.64 & -0.70 \\ & \text { Median } & -0.73 & -0.76 & 0.32 & \\ & \text { Size } & 61 & 49 & 12 & \\ & \text { SRT } & (12.18)^{* * *} & (2.55)^{* *} & (-0.44) & \end{array}$

Notes: This table reports mean and median abnormal returns and the standardized residual $\mathrm{t}$-tests (SRT) for the period the day before the announcement date to day after (e.g. AD-1 TO AD 1), day before the record date to day after (e.g. RD -1 TO RD 1), and "bigger" window - the day before announcement dates and the days after the record dates (e.g. AD-1 to RD +1). This table reports listed versus unlisted spun-off firms. This table also provides t-test statistics for the difference in mean abnormal returns across the different groupings.

*Significantly different from zero at the $10 \%$ level,

$* *$ Significantly different from zero at the $5 \%$ level, and

***Significantly different from zero at the $1 \%$ level.

\subsection{Regression results analysis}

The dependent variables are the cumulative abnormal returns generated by the three day event window (day -1 to day 1 ). The hypotheses examined include: the "getting back to basics" hypothesis, relative size hypothesis, engaging firm size hypothesis, solvency hypothesis. Model 4 and model 6 will not be used for hypotheses testing because they are both insignificant at the $10 \%$ level (their p-values exceed 0.1). Therefore, model 1, 2, 3, and 6 will be used to interpret results of hypothesis testing. CASHTOTA is introduced in the regression models to control the non-cash motive of the spin-off. This variable is negative and insignificant among all the 6 models. The regression outputs are presented in Table 8.

This study investigates whether announcement excess returns are influenced by the "increased focus" of the parent companies. The hypothesis suggests that the CAR will be greater for the "focus" group than the "non-focus." The relevant variable is LF, which is the multiplicative form of two dummy variables, namely FOCUSES and LISTED. This variable is equal to 1 if the parent spins off the subsidiary into different industry and also has it listed on the ASX. Although the magnitude of the variable is positive $1.88 \%$, it is statistically insignificant at $10 \%$ level. Therefore, there is not enough evidence to reject the null hypothesis that there is no difference between CAR attributable to the "focus" group and "nonfocus" group. This, along with the t-test presented in section 4.3.1, is not in accordance with the evidence found in the US and Europe.

Based on the finding of Veld and Veld-Merkoulova (2008) that a higher prespin-off leverage is associated with a positive abnormal stock returns. They argue that spin-off reduces firm size and cash flows, which increases bankruptcy risk. Since the negative relationship of asset value and asset volatility reverses for very high level of leverage (see also Leland \& Toft, 1996), "there 
is an increase in the probability that bankruptcy is avoided" (Veld \& VeldMerkoulova, 2008, p.106). Thus, higher prespin-off leverage is expected to be positively related with the abnormal returns to the stockholders of the parent firms. We use the ratio of total debt to total asset as a proxy for leverage. Models 1, 2, 3, and 5 demonstrate that there is evidence to support the alternative hypothesis that firms with higher level of debts experience higher CAR. This finding is consistent with the finding of Veld and Veld-Merkoulova (2004) for the European data. This variable is statistically significant at 5\% level in Models 2, 3, and 5 and significant at 10\% level in Model 1.

Existing literature suggests that the larger the proportion of the spun-off assets to the assets of the parent firm, the bigger piece of CAR (see Schipper, 1983). However, Model 6 is not reliable to make interpretation of the estimated results. Thus, it is not possible to test this hypothesis in this paper. The other hypothesis is that the wealth effect is larger when the portion of divested assets is larger (e.g., Hite \& Owners, 1983; Veld \& Veld-

\section{Table 8}

OLS regression output

\begin{tabular}{|c|c|c|c|c|c|c|}
\hline \multirow{2}{*}{$\begin{array}{l}\text { Independ- } \\
\text { ent varia- } \\
\text { bles }\end{array}$} & \multicolumn{6}{|c|}{ Regression output } \\
\hline & Model 1 & Model 2 & Model 3 & Model $4^{\mathrm{a}}$ & Model 5 & Mode $6^{\mathrm{a}}$ \\
\hline \multirow{2}{*}{ LISTED } & & & -0.0302 & & & \\
\hline & & & $(-0.8490)$ & & & \\
\hline \multirow{2}{*}{ FOCUS } & & & & 0.0117 & & \\
\hline & & & & $(0.4331)$ & & \\
\hline \multirow{2}{*}{$\mathrm{LF}$} & & & & & 0.0188 & \\
\hline & & & & & $(0.6822)$ & \\
\hline \multirow{2}{*}{ SIZE } & & & & & & 0.0214 \\
\hline & & & & & & $(0.5539)$ \\
\hline \multirow{2}{*}{ LMV } & -0.0059 & & & & & \\
\hline & $(-1.1026)$ & & & & & \\
\hline \multirow{2}{*}{ TDTOTA } & -0.1105 & -0.1502 & -0.1598 & -0.1569 & -0.1513 & -0.0428 \\
\hline & $(-1.7041)^{*}$ & $(-2.3550)^{* *}$ & $(-2.2378)^{* *}$ & $(-2.2494)^{* *}$ & $(-2.3662) * *$ & $(-0.7757)$ \\
\hline \multirow{2}{*}{$\begin{array}{l}\text { CASH- } \\
\text { TOTA }\end{array}$} & -0.0723 & -0.0658 & -0.0738 & -0.0666 & -0.0643 & \\
\hline & $(-1.6231)$ & $(-1.6342)$ & $(-1.6663)$ & $(-1.6014)$ & $(-1.5471)$ & \\
\hline \multirow{2}{*}{ RUNUP } & 0.0106 & 0.0113 & 0.0113 & 0.0110 & 0.0112 & 0.0115 \\
\hline & $(3.2584)^{* * *}$ & $(3.2026) * * *$ & $(2.8754) * * *$ & $(3.0009)^{* * *}$ & $(3.5971)^{* * *}$ & $(2.3137)^{* *}$ \\
\hline
\end{tabular}




\begin{tabular}{lcccccc}
\hline C & 0.0834 & 0.0578 & 0.0850 & 0.0556 & 0.0537 & 0.0209 \\
& $(2.0105)^{*}$ & $(2.5464)^{* *}$ & $(1.8560)^{*}$ & $(2.4794)^{* *}$ & $(2.3469)^{* *}$ & $(1.2668)$ \\
R-squared & 0.1449 & 0.1229 & 0.1430 & 0.1267 & 0.1313 & 0.1129 \\
$\begin{array}{l}\text { Adjusted R- } \\
\text { squared }\end{array}$ & 0.0838 & 0.0768 & 0.0818 & 0.0643 & 0.0693 & 0.0496 \\
F-statistic & 2.3714 & 2.6627 & 2.3359 & 2.0310 & 2.1166 & 1.7821 \\
& & & & & & \\
Probability & $0.0632 *$ & $0.0565^{*}$ & $0.0665^{*}$ & 0.1024 & $0.0908^{*}$ & 0.1652 \\
& & & & & & \\
Sample size & 61 & 61 & 61 & 61 & 61 & $46^{\mathrm{b}}$ \\
\hline
\end{tabular}

Notes: a Models that are presented but not used for hypotheses testing

*** Significant at the one per cent level

** Significant at the five per cent level

* Significant at the ten per cent level

b Only 46 out of 61 observation is available to calculate the relative size of the spin-off. 12 are unlisted spun-off firms, 3 firms are listed in other stock exchange (i.e. NSX). The cross-sectional regression output uses two tailed t-tests. To incorporate robustness, all regressions are White Heteroskedasticity-Consistent Standard Errors \& Covariance.

Merkoulova, 2004). Model 1 is the only model used to test this hypothesis. It demonstrates that size of the parent firms have a negative but insignificant effect on the CAR. Accordingly, this illustrates that the bigger the firm size of the parents, the smaller the CAR the shareholders experiences. We conclude that there is little evidence to support this hypothesis. This finding is inconsistent with finding of Hite and Owners (1983).

Surprisingly, the controlling variable RUNUP, which represents the possibility that market anticipates a spin-off announcement and begins to bid up prices prior to reflect the positive sentiment. We expect this variable has a negative sign, i.e. the magnitude of price reaction on announcement dates might be lower if share prices are bid up prior to the announcement dates. However, the regression results illustrate the opposite. This finding suggests that there might be herding effect and lagging effect of the bidding up. This requires more in-depth study.

\section{Conclusion}

This paper examines the impact of corporate spin-off announcements by Australian firms on the shareholders' wealth. The results from the event study show that spin- 
offs may create value to the shareholders by means of positive abnormal returns around announcement dates. Market reacts positively to the announcements of corporate spin-off regardless of business forms of spun-off entity (i.e. listed or unlisted). The results from regression analysis suggest that higher pre-leveraged firms benefit more from spinning off its subsidiaries. We find no evidence to support the other hypotheses such as "getting back to the basics," and "relative size effect hypothesis," However, spin-off may destroy value the shareholders by means of negative abnormal returns around record dates.

We collect data of spin-off announcements from 2002, in which the "Demerger Tax Relief" provision was enacted in Australia. However, time constraints preclude the undertaking of thorough examination of taxation consequences with respect to the spin-offs. Due to the limited access to bond data information and analyst coverage, we could not test "wealth transfer" and "information asymmetry" hypotheses. This research is also limited by the small sample size. The scope of this study is to investigate how market responds to the spin-off event in a short run, i.e. around announcement dates. Since stock values depend on long run performance of firms, a thorough analysis of long run performance of the engaging firms might provide some insight into capital market efficiency in the context of Australia

\section{References}

Allen, J. W., Lummer, S. L., McConnell, J. J., \& Reed, D. K. (1995). Can takeover losses explain spin-off gains? Journal of Financial and Quantitative Analysis, 30(4), 465-485.
Amihud, Y. (1986). Asset pricing and the bid-ask spread. Journal of Financial Economics, 17(2), 223-249.

Berger, P. G., \& Ofek, E. (1995). Diversification's effect on firm value. Journal of Financial Economics, 37(1), 39-65.

Bergh, D. D., Johnson, R. A., \& Dewitt, R.-L. (2008). Restructuring through spin-off or sell-off: Transforming information asymmetries into financial gain. Strategic Management Journal, 29(2), 133-148.

Brown, S. J., \& Warner, J. B. (1985). Using daily stock returns. Journal of Financial Economics, 14(1), 3-31.

Campa, J. M., \& Kedia, S. (2002). Explaining the diversification discount. The Journal of $\mathrm{Fi}$ nance, 57(4), 1731-1762.

Chemmanur, T. J., \& Yan, A. (2004). A theory of corporate spin-offs. Journal of Financial Economics, 72(2), 259-290.

Cooney, M. R., Finn, F., \& Karl, A. (2004). Australian divestiture activity: An examination of gains to sell-off announcements. Australian Journal of Management, 29(1 Suppl.), 135151.

Cusatis, P. J., Miles, J. A., \& Woolridge, J. R. (1993). Restructuring through spinoffs: The stock market evidence. Journal of Financial Economics, 33(3), 293-311.

Daley, L., Mehrotra, V., \& Sivakumar, R. (1997). Corporate focus and value creation evidence from spinoffs. Journal of Financial Economics, 45(2), 257-281.

Desai, H., \& Jain, P. C. (1999). Firm performance and focus: Long-run stock market performance following spinoffs. Journal of $\mathrm{Fi}$ nancial Economics, 54(1), 75-101.

Edelman, R. B., \& Baker, H. K. (1990), Liquidity and stock exchange listing. Financial Review, 25, 231-249. doi: 10.1111/j.15406288.1990.tb00794.x 
Galai, D., \& Masulis, R. W. (1976). The option pricing model and the risk factor of stock. Journal of Financial Economics, 3(1), 5381.

Gujarati, D. N. (2003). Basic econometrics. NY: McGraw Hill Book Co.

Habib, M. A., Johnsen, D. B., \& Naik, N. Y. (1997). Spinoffs and information. Journal of Financial Intermediation, 6(2), 153-176.

Hite, G. L., \& Owers, J. E. (1983). Security price reactions around corporate spin-off announcements. Journal of Financial Economics, 12(4), 409-436.

Krishnaswami, S., \& Subramaniam, V. (1999). Information asymmetry, valuation, and the corporate spin-off decision. Journal of $\mathrm{Fi}$ nancial Economics, 53(1), 73-112.

Leland, H. E., \& Klaus, B. T. (1996). Optimal capital structure, endogenous bankruptcy, and the term structure of credit spreads. The Journal of Finance, 51(3), 987-1019.

MacKinlay, A. C. (1997). Event studies in economics and finance. Journal of Economic Literature, 35(1), 13-39.

Maxwell, W. F., \& Rao, R. P. (2003). Do spinoffs expropriate wealth from bondholders? The Journal of Finance, 58(5), 2087-2108.

Miles, J. A., \& Rosenfeld, J. D. (1983). The effect of voluntary spin-off announcements on shareholder wealth. The Journal of Finance, 38(5), 1597-1606.
Patell, J. M. (1976). Corporate forecasts of earnings per share and stock price behavior: Empirical test. Journal of Accounting Research, 14(2), 246-276.

Ross, S. A. (2011). Fundamentals of corporate finance. North Ryde, NSW: McGraw-Hill.

Schipper, K., \& Smith, A. (1983). Effects of recontracting on shareholder wealth: The case of voluntary spin-offs. Journal of Financial Economics, 12(4), 437-467.

Schmidt, R. J. (1987). Corporate divestiture: Pruning for higher profits. Business Horizons, 30(3), 26-31.

Thomas, B., Jay, F. C., \& Kuldeep, S. (1999). Spinoffs, spreads, and information asymmetry. Unpublished Working Paper.

Veld, C., \& Veld-Merkoulova, Y. V. (2004). Do spin-offs really create value? The European case. Journal of Banking and Finance, 28(5), 1111-1135.

Veld, C., \& Veld-Merkoulova, Y. V. (2008). An empirical analysis of the stockholder-bondholder conflict in corporate spin-offs. Financial Management, 37(1), 103-124.

Yoon, C.-S., \& Ariff, M. (2007). Corporate spinoffs, their price reactions and determinants in Malaysia. The International Journal of Banking and Finance, 5(1), 31.

Zakaria, N., \& Arnold, G. C. (2012). Do Malaysian spin-offs create value? Asian Journal of Finance \& Accounting, 4(1), 151-172. 